\title{
FACTORS ASSOCIATED WITH THE DEVELOPMENT OF EARLY INFECTION AFTER SURGICAL TREATMENT OF FRACTURES
}

\author{
FATORES ASSOCIADOS AO DESENVOLVIMENTO DE INFECÇÃO \\ PRECOCE APÓS TRATAMENTO CIRÚRGICO DAS FRATURAS
}

\author{
João Eurípedes de Alcântara Junior ${ }^{1}$, Rogger Aguiar de Aguiar ${ }^{1}$, Jose Gilvan Leite Sampalo Neto ${ }^{1}$, Matheus Lemos Azi ${ }^{1}$, \\ DaVid Sadigursky ${ }^{1}$, Daniel Figueiredo de Alencar ${ }^{1}$
}

1. Manoel Victorino Hospital, Secretary of Health for the State of Bahia. Praça Conselheiro Almeida Couto S/N, 40050-410, Salvador, Bahia, Brazil.

\section{ABSTRACT}

Objective: Infection after the internal fixation of fractures is a major complication. Early infection is particularly challenging, because it occurs when the fracture is not yet united. The objective of this study is to identify possible factors related to the development of early infection in patients treated with internal fixation for fractures. Method: This retrospective observational study analyzed 24 patients with long bone fractures who underwent internal fixation and developed infections in the post-operatory period. The infections were classified as early (diagnosis in the first two weeks after surgery) or late (diagnosis after 2 weeks). Results: Of the 24 patients studied, 11 (46\%) developed early infections and 13 (54\%) were diagnosed with late infections. The early infection group was significantly younger (37.8 versus $53.1[p=0.05])$ and underwent more surgeries prior to internal fixation (1.2 versus $0.2[p<0.00]$ ). Conclusion: Risk factors for the development of early infection in the postoperative period should be considered when treating patients with internal fracture fixation in order to diagnose this condition as early as possible. Level of Evidence IV; Case series.

Keywords: Fracture healing. Osteomyelitis. Surgical wound infection.

\section{RESUMO}

Objetivo: A infecção após a fixação interna das fraturas é uma complicação grave, sendo a infecção precoce particularmente desafiadora, pois acontece quando a fratura ainda não está consolidada. O objetivo deste estudo é identificar fatores relacionados com o desenvolvimento de infecção precoce em pacientes submetidos à fixação interna de fraturas. Método: Estudo retrospectivo que envolveu 24 pacientes com fraturas de ossos longos submetidos à fixação interna, que evoluíram com infecção no pós-operatório. A infecção foi classificada como precoce (diagnóstico nas primeiras duas semanas após a fixação interna) e tardia (diagnóstico após 2 semanas da realização da fixação). Resultados: Dos 24 pacientes estudados, 11 (46\%) desenvolveram infecção precoce e 13 (54\%) tiveram infecção tardia. Os pacientes portadores de infecção precoce eram mais jovens (37,8 anos versus 53,1 anos [ $p=0,05]$ ) e foram submetidos a um maior número de cirurgias antes da fixação interna (1,2 versus 0,2 [ $p<0,00])$. Conclusão: É recomendável levar em consideração os fatores de risco de desenvo/vimento de infecção no pós-operatório em pacientes submetidos à fixação interna de fraturas visando realizar o diagnóstico o mais breve possível. Nível de Evidência IV; Série de casos.

Descritores: Consolidação da fratura. Osteomielite. Infecção da ferida cirúrgica.

Citation: Alcântara Junior JE, Aguiar RA, Sampaio Neto JGL, Azi ML, Sadigursky D, Alencar DF. Factors associated with the development of early infection after surgical treatment of fractures. Acta Ortop Bras. [online]. 2018;26(1):22-6. Available from URL: http://www.scielo.br/aob.

\section{INTRODUCTION}

Infection of the surgical site is a severe complication related to fracture treatment, and is associated with increases in morbidity, mortality, and costs. ${ }^{1}$ The rate of infection associated with internal fracture fixation may be as high as $3.6 \%$ to $8.1 \%$ for closed fractures and $30 \%$ for open fracture. . $^{2}$ This high incidence of post-operative infection in fractures contrasts with a risk of less than $2 \%$ in elective joint reconstruction surgeries. ${ }^{3-5}$

Many factors have been considered to predispose the development of post-surgical infection, and are related to the host, trauma, and treatment itself; identification of these factors is crucial in planning prevention strategies..$^{1,5-8}$ Surgical treatment of fractures occurs in an area which is already traumatized, where the need for early intervention often overrides the desire to wait the time necessary for complete recovery of the soft tissue and minimize comorbidities. ${ }^{6}$ The route of infection can be classified as perioperative (contamination during or immediately after the surgery), contiguous (organisms inoculated into the wound from an adjacent focus, or loss of integrity in the soft tissue), or hematogenic (infectious agent migrates from a distant focus through the bloodstream). ${ }^{2}$

All authors declare no potential conflict of interest related to this article.

Work conducted at the Manoel Victorino Hospital, Secretary of Health for the State of Bahia. Praça Conselheiro Almeida Couto S/N, 40050-410, Salvador, Bahia, Brazil. Correspondence: Matheus Lemos Azi. Manoel Victorino Hospital, Secretary of Health for the State of Bahia. Praça Conselheiro Almeida Couto S/N, 40050-410, Salvador, Bahia, Brazil.mlazi@hotmail.com 
In terms of time of development, infections can be early or late. ${ }^{2,9}$ Early infection tends to be the result of perioperative or contiguous infection, and is particularly challenging because it occurs when the fracture is not yet united. 2,5

The objective of this study is to identify factors related to the patient, fracture, and treatment, which can lead to the development of early infection in patients who undergo internal fracture fixation of the long bones.

\section{METHODS}

This retrospective, observational study evaluated data from patients who developed surgical site infections (SSI) after treatment for fracture between January 2014 and December 2015 at a reference hospital for orthopedic treatment. After approval by the institutional review board (CAAE: 49142815.9.0000.0052), we analyzed the medical records of the patients identified by the commission for hospital infection control as having developed post-surgical infection. The group included patients with fractures of the long bones who were surgically treated with internal fixation and developed postoperative infections. The study excluded patients who developed infection after surgical treatment at other hospitals, treatment with external fixation (EF), treatment with arthroplasty, or patients who underwent internal fracture fixation in the hand, foot, or the flat bones such as the pelvis and acetabulum. We also excluded cases with incomplete medical record data.

Patient medical records were reviewed to identify factors that could be related to an increased risk of developing infection after surgical treatment of fractures. We analyzed demographic characteristics (age and sex), host-related factors (local and systemic comorbidities), and characteristics related to trauma (trauma mechanism, organs and systems affected, and number of fractures). The following were considered systematic comorbidities: high blood pressure, diabetes mellitus, chronic kidney disease, congestive heart failure, obesity (body mass index $\geq 30 \mathrm{~kg} / \mathrm{m}^{2}$ ), and tobacco and alcohol use. Local comorbidities were abrasions, hyperemia, wounds without signs of infection, and wounds with signs of infection. Additionally, patients were classified according to the American Society of Anesthesiology system as well as the system proposed by Cierny-Mader. ${ }^{8}$ The fractures were classified according to the AO/OTA classification for fractures and dislocations ${ }^{10}$ and the open fractures were classified according to the Gustilo and Anderson classification. ${ }^{11}$

The infections were classified as superficial incision (involving skin and subcutaneous tissue), deep incision (involving deep tissues), or organ/space (involving the bone); definition of these groups considered the recommendations from the United States Centers for Disease Control and Prevention..$^{12}$ Infection was also classified according to the time between internal fixation and early diagnosis (within the first two weeks after internal fixation) and late diagnosis (two weeks after internal fixation was performed). 2,9

Of a total of 87 patients who developed post-surgical infection during the study period, 24 patients with closed or exposed fractures of the long bones who underwent internal fixation and fulfilled the inclusion criteria were selected. The demographic characteristics of these patients are presented in Table 1. Sixty-three patients were excluded: those with fractures of the short or flat bones, infections after surgeries performed at other hospitals, fractures treated with arthroplasty, and patients with incomplete data.

Traffic accidents were the cause of the trauma in $58 \%$ of the patients. The left side was more affected by postoperative infection, in 13 (54\%) of cases. All patients had associated fractures, with an average of 1 (1-3, SD: 0.6) fracture per patient, and no patient exhibited injuries to other organs or systems. The most frequently affected bone was the femur, with 16 (67\%) fractures that progressed to infection in the post-operative period. Table 2 presents the description of the characteristics of the trauma and the affected segment.
Table 1. Demographic characteristics of study participants

\begin{tabular}{c|c|c|c|c}
\hline Parameter & Description & n/ mean & $\%$ & Interval (SD) \\
\hline Number of subjects & $\mathrm{n}$ & 24 & 100 & -- \\
\hline Mean age (years) & Age & 46 & -- & $15-85(19.3)$ \\
\hline Sex & Male & 15 & $62.5 \%$ & -- \\
\hline ASA & Female & 9 & $37.5 \%$ & -- \\
\hline & $\mathrm{I}$ & 15 & $62.5 \%$ & -- \\
\hline & $\mathrm{II}$ & 7 & $29.2 \%$ & -- \\
\hline & $\mathrm{III}$ & 2 & $8.3 \%$ & -- \\
\hline Host classification (Cierny) & $\mathrm{A}$ & 15 & $62.5 \%$ & -- \\
\hline & $\mathrm{B}$ & 9 & $37.3 \%$ & -- \\
\hline & $\mathrm{C}$ & 0 & $0.0 \%$ & -- \\
\hline Comorbidities & Diabetes & 3 & $12.5 \%$ & -- \\
\hline & HBP & 3 & $12.5 \%$ & -- \\
\hline & Obesity & 2 & $8.4 \%$ & -- \\
\hline & CKD & 1 & $4.2 \%$ & -- \\
\hline Tobacco use & CHF & 1 & $4.2 \%$ & -- \\
\hline & Other & 2 & $8.4 \%$ & -- \\
\hline Alcohol use & No & 20 & $83.3 \%$ & -- \\
\hline & Yes & 4 & $16.8 \%$ & \\
\hline & No & 22 & $91.7 \%$ & -- \\
\hline & Yes & 2 & $8.4 \%$ & -- \\
\hline
\end{tabular}

n number. SD: standard deviation ASA, classification of patient's physical state according to the American Society of Anesthesiology. Cierny, host classification according to Cierny and Mader. $\mathrm{HBP}$, high blood pressure $\mathrm{CKD}$, chronic kidney disease $\mathrm{CHF}$, congestive heart failure.

Table 2. Trauma mechanism and injuries associated with the fracture that progressed to infection.

\begin{tabular}{|c|c|c|c|c|}
\hline Parameter & Description & $\mathrm{n} /$ mean & $\%$ & Interval (SD) \\
\hline \multirow[t]{2}{*}{ Side } & Left & 13 & $54.1 \%$ & -- \\
\hline & Right & 11 & $45.9 \%$ & -- \\
\hline \multirow[t]{5}{*}{ Type of trauma } & Motorcycle & 11 & $45.8 \%$ & -- \\
\hline & Fall & 8 & $33.3 \%$ & -- \\
\hline & Car & 3 & $12.5 \%$ & -- \\
\hline & Blunt trauma & 1 & $4.2 \%$ & -- \\
\hline & Firearm trauma & 1 & $4.2 \%$ & -- \\
\hline \multirow[t]{10}{*}{ Fractured Segment (Class. AO) } & 11 & 1 & $4.2 \%$ & -- \\
\hline & 12 & 2 & $8.4 \%$ & -- \\
\hline & 13 & 1 & $4.2 \%$ & -- \\
\hline & 22 & 1 & $4.2 \%$ & -- \\
\hline & 31 & 3 & $12.5 \%$ & -- \\
\hline & 32 & 10 & $41.6 \%$ & -- \\
\hline & 33 & 3 & $12.5 \%$ & -- \\
\hline & 41 & 1 & $4.2 \%$ & -- \\
\hline & 42 & 1 & $4.2 \%$ & -- \\
\hline & 43 & 1 & $4.2 \%$ & -- \\
\hline Fracture type (closed) & Closed & 20 & $83.3 \%$ & -- \\
\hline \multirow[t]{5}{*}{ Fracture type (closed) } & $\mathrm{Gl}$ & -- & -- & -- \\
\hline & Gll & 2 & $8.4 \%$ & -- \\
\hline & GIII-A & 1 & $8.4 \%$ & -- \\
\hline & GIII-B & -- & -- & -- \\
\hline & GIII-C & 1 & $4.2 \%$ & -- \\
\hline \multirow[t]{2}{*}{ Soft tissue reconstruction } & No & 24 & $100.0 \%$ & -- \\
\hline & Yes & 0 & $0.0 \%$ & -- \\
\hline \multirow[t]{4}{*}{ Skin injury } & No injury & 15 & $62.5 \%$ & -- \\
\hline & $\begin{array}{c}\text { Abrasion/ } \\
\text { hyperemia }\end{array}$ & 4 & $16.6 \%$ & -- \\
\hline & Wound & 4 & $16.6 \%$ & -- \\
\hline & Infected wound & 1 & $4.2 \%$ & -- \\
\hline
\end{tabular}

$\mathrm{G}$, degree in classification by Gustillo and Anderson. 
The patients were admitted to the unit for treatment on average 17 days (0-67, SD: 20.9) after the trauma. The laboratory tests conducted upon admission are described in Table 3. Four (17\%) patients received blood transfusions prior to surgery, and 15 (63\%) after surgery. Sixteen 16 (67\%) patients required transfusion before and after surgery, receiving an average of 2.7 units (0-14, SD: 3.5) of packed red blood cells. An average of 0.7 surgeries (0-2, SD: 0.7) were performed prior to the internal fracture fixation which progressed to infection, and the internal fixation procedure was performed an average of 27 days (0-91, SD: 22.0) after the trauma.

The data were stored in digital format and subsequently analyzed using Stata statistical software, version 13 (Corastar, St George, Utah, USA). Normality of the continuous variables was tested using the Shapiro-Wilk test and then analyzed with the t-test or Kruskal-Wallis test. The categorical variables were analyzed with the chi-square test. A significance level of $\alpha=5 \%$ was adopted. Logistical regression with a confidence interval of $95 \%$ and analysis of variance were utilized to create graphs.

\begin{tabular}{|c|c|c|c|}
\hline Laboratory results at admission & $\mathrm{n} /$ mean & $\%$ & Interval (SD) \\
\hline Hemoglobin $(\mathrm{g} / \mathrm{dL})$ & 11 & -- & $9.1-15.4(1.9)$ \\
\hline Hematocrit (\%) & 35 & -- & $24.7-50.2(5.9)$ \\
\hline Leukogram (\%/ml) & 9,865 & -- & $\begin{array}{c}4,400-15,400 \\
(3,213.4)\end{array}$ \\
\hline Platelets (n/ml) & 332,000 & -- & $\begin{array}{c}186,000-912,000 \\
(156,813.9) \\
\end{array}$ \\
\hline Blood sugar (mg/dL) & 143 & -- & $94-263(53.6)$ \\
\hline Urea (mg/dL) & 32 & \begin{tabular}{|l|}
-- \\
\end{tabular} & $10-89(14.6)$ \\
\hline Creatinine $(\mathrm{mg} / \mathrm{dL})$ & 1 & -- & $0.4-4.4(0.7)$ \\
\hline Erythrocyte sedimentation rate $(\mathrm{mm})$ & 35 & \begin{tabular}{|l|}
-- \\
\end{tabular} & $0.6-52(18.8)$ \\
\hline $\mathrm{PCR}(\mathrm{mg} / \mathrm{l})$ & 36 & -- & $6-96(31.5)$ \\
\hline
\end{tabular}

n, number. PCR, C-reactive protein.

\section{RESULTS}

In three cases (12.5\%), the infection was classified as superficial, deep in 10 cases (41.6\%), and as affecting organs/space in 11 (45.9\%). Postoperative infection was diagnosed an average of 53 days (1-293; SD: 76.8) after internal fixation, and in 11 cases (46\%) the infection was classified as early, and late in 13 (54\%). Cultures taken from 15 (63\%) patients after debridement of the infection were positive. After infection was diagnosed, an average of 2.8 surgical procedures (1-8; SD: 1.7) were performed in the affected segment. The patients received intravenous antibiotics on an inpatient basis for an average of 24 days (0-97, SD: 21.7). The characteristics of the infectious process in the cases included in this study are presented in Table 4.

Analysis of prognostic factors for the development of early infection The patients who developed early infections were significantly younger (early, 37.8 years old [SD: 14.2], versus late, 53.1 years [SD: 20.7], $p=0.05)$ and underwent more surgeries prior to the internal fracture fixation that progressed to infection (early: 1.2 procedures [SD: 0.6] versus late 0.2 [SD: 0.4] surgeries, $p<0.00$ ). (Figure 1) The use of temporary external fixation to stabilize the fracture was associated with a significant risk of developing late infection ( $p=0.03)$. There was no relationship between delaying internal fracture fixation and the start of the infectious process ( $p=0.28$ ). (Figure 2) None of the other parameters assessed in the study demonstrated a relationship with the start of the infectious process.

\section{DISCUSSION}

Infection associated with internal fracture fixation is typically caused by biofilm-producing bacteria. ${ }^{4}$ Shortly after implantation, a layer composed mainly of adhesins forms around the biomaterial, allowing adhesion by planktonic forms of infective organisms. Through cell division, recruitment of new free forms, and secretion of bacterial products, the organisms form a colony attached to the implant and protected

Table 4. Diagnosis and treatment of infection.

\begin{tabular}{|c|c|c|c|c|c|c|}
\hline Case & Fracture & Diag. (days) & Culture after internal fixation & EF (CHECK) & Implant Used & SSI classification \\
\hline \multicolumn{7}{|c|}{ Early infection } \\
\hline 24 & $32 \mathrm{~A} 2$ & 1 & Not collected & No & Long cephalomedullar rod & Osteomyelitis \\
\hline 21 & $33 \mathrm{C} 3$ & 2 & Not collected & No & Internal fixator distal fêmur & Osteomyelitis \\
\hline 10 & $22 \mathrm{~A} 2$ & 6 & Not collected & Yes & DCP plate & Deep incision \\
\hline 19 & $32 A 3$ & 7 & Klebsiella pneumoniae & No & Long cephalomedullar rod & Osteomyelitis \\
\hline 2 & 32B3 & 11 & Proteus Mirabilis & No & DCP plate & Deep incision \\
\hline 12 & $32 \mathrm{C} 2$ & 11 & MRSA & No & Intramedullary nail & Osteomyelitis \\
\hline 23 & 43B3 & 11 & MRSA & Yes & DCP plate & Deep incision \\
\hline 6 & $32 \mathrm{C} 2$ & 12 & Negative & No & Intramedullary nail & Osteomyelitis \\
\hline 8 & 32B2 & 14 & Negative & Yes & DCP plate & Deep incision \\
\hline 20 & $32 \mathrm{~A} 1$ & 14 & Pseudomonas aeruginosa & Yes & Intramedullary nail & Osteomyelitis \\
\hline 22 & $11 \mathrm{~A} 2$ & 14 & Pseudomonas aeruginosa & No & T plate & Deep incision \\
\hline \multicolumn{7}{|c|}{ Late infection } \\
\hline 16 & $13 \mathrm{C} 3$ & 15 & Enterobacter cloacae & No & Reconstruction plate & Deep incision \\
\hline 14 & $12 \mathrm{C} 3$ & 17 & MRSA & No & DCP plate & Superficial incision \\
\hline 17 & $31 \mathrm{~A} 1$ & 17 & Pseudomonas aeruginosa & No & Short cephalomedullar rod & Osteomyelitis \\
\hline 4 & $33 \mathrm{C} 1$ & 22 & Staphylococcus aureus & No & DCS plate & Deep incision \\
\hline 1 & 32B2 & 25 & Not collected & No & Intramedullary nail & Deep incision \\
\hline 3 & $32 \mathrm{A3}$ & 47 & Not collected & No & DCP plate & Superficial incision \\
\hline 5 & $31 \mathrm{~A} 2$ & 48 & Pseudomonas aeruginosa & No & DHS plate & Osteomyelitis \\
\hline 7 & 32B2 & 82 & Negative & No & DCP plate & Superficial incision \\
\hline 9 & $41 \mathrm{C} 1$ & 109 & Staphylococcus epidermitis & No & DCP plate & Deep incision \\
\hline 13 & $31 \mathrm{~A} 2$ & 121 & Pseudomonas aeruginosa & No & DHS plate & Osteomyelitis \\
\hline 15 & $42 \mathrm{~A} 1$ & 179 & Staphylococcus aureus & No & DCP plate & Osteomyelitis \\
\hline 18 & $12 \mathrm{~A} 1$ & 217 & Not collected & No & DCP plate & Deep incision \\
\hline 11 & $33 \mathrm{A3}$ & 293 & Not collected & No & DCS plate & Osteomyelitis \\
\hline
\end{tabular}




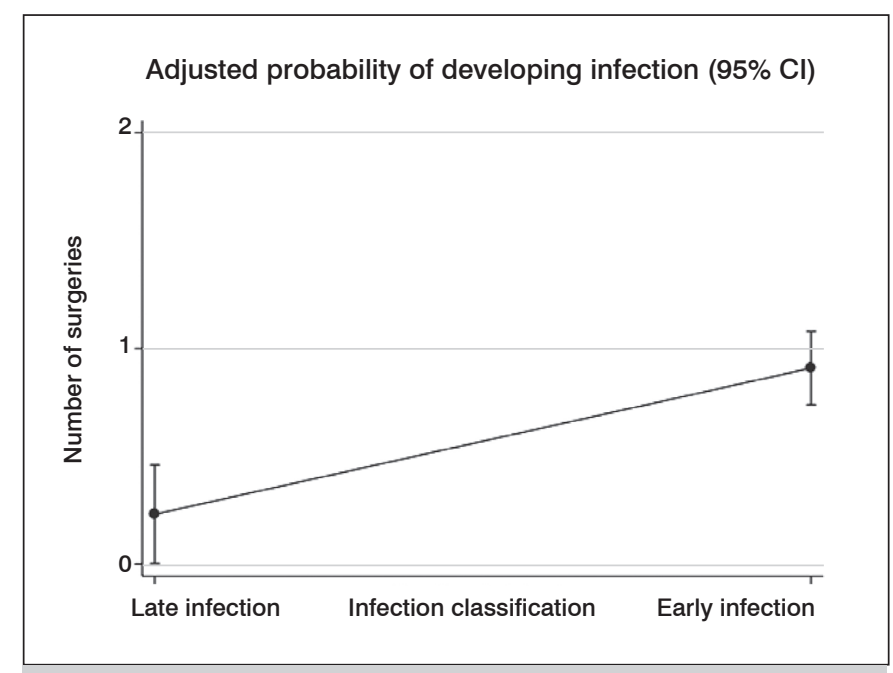

Figure 1. Adjusted probability of developing infection according to the number of surgeries performed before internal fixation of the fracture. Logistic regression.

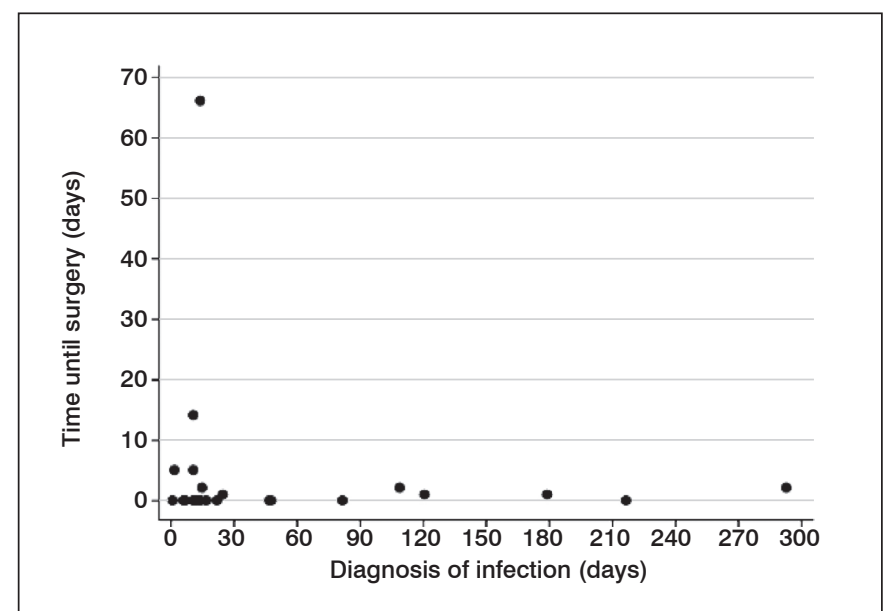

Figure 2. Relationship between trauma/time elapsed until internal fracture fixation and development of early and late infection. Analysis of variance.

by biofilm. ${ }^{2}$ These organisms surrounded by biofilm are metabolically less active, facilitating the development of antibiotic resistance. ${ }^{3,4}$

Treatment of infection after internal fracture fixation generally involves a combination of surgery and the use of antibiotics. Surgery includes aggressive debridement of all devitalized tissue and removal of the implants, and sometimes coverage with muscle flaps to provide improved wound vascularization. ${ }^{8}$ However, in the presence of early infection the main objective becomes fracture healing. ${ }^{2}$ Consequently, early infection represents a therapeutic challenge because it occurs in a non-united fracture, where the stability provided by the implant is essential. At the same time, the presence of the implant in the wound plays an important role in the persistence of the infectious process. ${ }^{2,5}$

Willenneger and Roth ${ }^{9}$ presented the results from a series of 40 patients treated for infection after open reduction and internal fixation using a plate. These authors proposed grouping patients according to the time elapsed between surgery and the onset of infection symptoms as early (less than 2 weeks), delayed (between 2 and 10 weeks), and late (more than 10 weeks). However, these intervals were arbitrarily established based on the authors' clinical experience. Schmidt et al. ${ }^{13}$ incorporated these parameters as part of a broad classification for osteomyelitis, but stressed that defining the start time and the time elapsed to infection based on only clinical parameters can be faulty. For these authors, histological assessment is much more precise, particularly when seeking to define whether the infection is acute or chronic (defined as those in which the infectious process leads to chronic inflammatory alterations in the tissue, especially bone necrosis). ${ }^{13-15}$

Trampuz and Zimmerli ${ }^{2}$ also defined early infection as beginning up to two weeks after the surgical treatment, and believed that this type of infection denotes perioperative contamination and/or the presence of high virulence bacteria. According to McPherson et al., ${ }^{7}$ early postoperative infection should be defined as occurring up to the fourth week after surgery. Infectious processes which begin after this period comprise the late forms, and suggest contamination by low-virulence germs or occasionally hematogenous contamination. ${ }^{2}$ Bowen and Widmaier ${ }^{6}$ investigated risk factors for infection after open fractures, and the only predictor for infection they found was tobacco use. Matos et al. ${ }^{16}$ also looked for risk factors for acute infection in open fractures and found an association between increased time until treatment and risk of infection. Oliveira et al. ${ }^{17}$ analyzed the risk of infection in 1,103 patients with closed fractures who underwent internal fixation compared with 1,887 open fractures, and found a higher incidence of infection in cases of exposed fractures. Dellinger et al. ${ }^{18}$ assessed factors associated with the development of infection in open fractures and demonstrated a higher incidence of infection in leg fractures. Srour et al. ${ }^{19}$ conducted a prospective study on progress in 315 patients with open fractures after surgical treatment and found that superficial infections accounted for most of the early SSI.

In the present study, the factors related to higher risk for developing early infection were the number of surgeries before the definitive procedure and patient age. One possible explanation is the fact that younger patients are more frequently involved in high-energy traumas which lead to more complex fractures with greater damage to soft tissue; these require more surgeries and consequently this group has a greater risk of infection.

This study has a number of limitations. The retrospective design and the small number of patients are factors that limit the clinical applicability of the findings. The factors related to trauma, patient, infection, and treatment varied, restricting the creation of homogeneous subgroups for statistical analysis. Consequently, infections involving the arms and legs were seen, as well as fixation involving different implants. Furthermore, the ability to establish an accurate diagnosis of infection based on clinical criteria can be considered a limiting factor.

\section{CONCLUSION}

Based on the findings of this study, we recommend considering the risk factors for early postoperative infection in patients who undergo internal fracture fixation to increase the chance that early diagnosis can be made and therapeutic measures taken as soon as possible. Multi-center studies involving more patients could validate the findings of this study and identify other possible factors related to the development of early infection after surgery to treat fractures.

AUTHORS' CONTRIBUTIONS: Each author made significant individual contributions to this manuscript. JEAJ (0000-0003-4790-9134)* acquired the data, drafted the article, and approved the final version of the manuscript. RAA (0000-0003-1218-5412)* and JGLSN (0000-0002-5582-7158)* drafted the article and approved the final version of the manuscript. MLA (0000-0002-4456-6423)* conceived and designed the study, analyzed and interpreted the data, drafted the article, and approved the final version of the manuscript. DS (0000-0003-3437-6180* and DFA (0000-0003-3006-7698)* conceived and designed the study and approved the final version of the manuscript. *ORCID (Open Researcher and Contributor ID). 


\section{REFERENCES}

1. Bosco JA 3rd, Slover JD, Haas JP. Perioperative strategies for decreasing infection: a comprehensive evidence-based approach. Instr Course Lect. 2010;59:619-28.

2. Trampuz A, Zimmerli W. Diagnosis and treatment of infections associated with fracture-fixation devices. Injury. 2006;37(Suppl 2):S59-66.

3. Diefenbeck M, Mückley T, Hofmann GO. Prophylaxis and treatment of implant related infections by local application of antibiotics. Injury. 2006;37(Suppl 2): S95-104.

4. Campoccia D, Montanaro L, Arciola CR. The significance of infection related to orthopedic devices and issues of antibiotic resistance. Biomaterials. 2006;27(11):2331-9.

5. Darouiche RO. Treatment of infections associated with surgical implants. N Engl J Med. 2004;350(14):1422-9.

6. Bowen TR, Widmaier JC. Host classification predicts infection after open fracture Clin Orthop Relat Res. 2005;(433):205-11.

7. McPherson EJ, Woodson C, Holtom P, Roidis N, Shufelt C, Patzakis M. Periprosthetic total hip infection: outcomes using a staging system. Clin Orthop Relat Res. 2002;(403):8-15.

8. Cierny G 3rd. Surgical treatment of osteomyelitis. Plast Reconstr Surg. 2011;127(Suppl 1):190S-204S.

9. Willenegger $\mathrm{H}$, Roth $\mathrm{B}$. Treatment tactics and late results in early infection following osteosynthesis. Unfallchirurgie. 1986;12(5):241-6.

10. Fracture and dislocation compendium. Orthopaedic Trauma Association Committee for Coding and Classification. J Orthop Trauma. 1996;10 (Suppl 1):v-ix, 1-154.

11. Gustilo RB, Anderson JT. Prevention of infection in the treatment of one thousand and twenty-five open fractures of long bones: retrospective and prospective analyses. J Bone Joint Surg Am. 1976;58(4):453-8.

12. Mangram AJ, Horan TC, Pearson ML, Silver LC, Jarvis WR. Guideline for Prevention of Surgical Site Infection, 1999. Centers for Disease Control and Prevention (CDC) Hospital Infection Control Practices Advisory Committee. Am J Infect Control. 1999;27(2):97-132

13. Schmidt HG, Diefenbeck M, Krenn V, Abitzsch D, Militz M, Tiemann AH, et al Classification of haematogenous and post-traumatic osteomyelitis. Z Orthop Unfall. 2014;152(4):334-42.

14. Waldvogel FA, Medoff G, Swartz MN. Osteomyelitis: a review of clinical features, therapeutic considerations and unusual aspects (second of three parts). N Eng J Med. 1970;282(5):260-6.

15. Gentry LO. Osteomyelitis: options for diagnosis and management. J Antimicrob Chemother. 1988;21 (Suppl C):115-31.

16. Matos MA, Lima LG, de Oliveira LA. Predisposing factors for early infection in patients with open fractures and proposal for a risk score. J Orthop Traumatol. 2015;16(3):195-201.

17. Oliveira PR, Carvalho VC, Felix CS, Paula AP, Silva JS, Lima ALLM. Infecção de sítio cirúrgico após fixação de fraturas fechadas e expostas - Incidência e perfil microbiológico. Rev Bras Ortop. 2016;51(4):396-9.

18. Dellinger EP, Miller SD, Wertz MJ, Grypma M, Droppert B, Anderson PA. Risk of infection after open fracture of the arm or leg. Arch Surg. 1988;123(11):1320-7.

19. Srour M, Inaba K, Okoye O, Chan C, Skiada D, Schnüriger B, et al. Prospective evaluation of treatment of open fractures: effect of time to irrigation and debridement. JAMA Surg. 2015;150(4):332-6. 